Annals of Warsaw University of Life Sciences - SGGW

Land Reclamation No 48 (2), 2016: 173-184

(Ann. Warsaw Univ. Life Sci. - SGGW, Land Reclam. 48 (2), 2016)

\title{
Potential effect of future climate changes on productivity of selected crops in Poland
}

\author{
BARBARA BRZÓSKA, ADAM JACZEWSKI \\ Institute of Meteorology and Water Management - National Research Institute
}

\begin{abstract}
Potential effect of future climate changes on productivity of selected crops in Poland. Future projections of selected climate indices have been used to assess potential effects of climate changes on productivity of selected crops in Poland. CMIP5 global climate models' results for the future period (2006-2035) and historical one (1981-2010) are used in the study. Models predict decrease in count of days with extreme low temperatures and increase in count of days with extreme high temperatures. An increase in the number of days with very heavy precipitation is also predicted. Not all climate change effects have negative impact on crop productivity in Poland but all of them confirm requirements to put into practice mitigation and adaptation strategies for Poland's agriculture.
\end{abstract}

Key words: CMIP5, climate indices, crop production, climate scenarios

\section{INTRODUCTION}

Changing climate has a major impact on the economy and agriculture (IPCC 2014). In the development of various national strategies from an economic point of view, it is necessary to consider projected changes of meteorological parameters. For agricultural production, weather conditions are the main determining factor. This will allow for more accurate determination of the climate change impact and better planning of plantings and adaptation of technical solutions to the new conditions (Kundzewicz and Kozyra 2011).
The most important research tools of modern climatology are three-dimensional models of the general circulation of the atmosphere and ocean or global climate models (GCMs) which describe the evolution of the climate system on global scale. The results of GCMs are extensively evaluated for the preparation of the Intergovernmental Panel on Climate Change (IPCC) assessment reports. Recently published fifth assessment report is based on results of the fifth phase of the Coupled Model Intercomparison Project - CMIP5 (Taylor et al. 2012). In addition to long-term experiments (until the end of the century), CMIP5 provided also near-term simulations or decadal predictions (Meehl et al. 2009) to allow for predicting climate statistics for times when the initial climate state may exert some detectable influence. This work is based on results of those experiments and details on them can be found in publication by Goddard et al. (2013).

The most important weather factors directly affecting crop production are: air and ground temperature, air humidity, precipitation, solar radiation, and wind. Each of them has a direct impact on plant growth resulting from interaction between these parameters. The purpose of this work is to evaluate the changes of selected climate indices in Poland based 
on the decadal predictions, at different time scales, as well as to demonstrate spatial differences.

\section{MATERIAL AND METHODS}

The investigation is based on the results of decadal predictions simulated by six GCM models (Table), each with six runs, named: r1i1p1, r2i1p1, r3i1p1, r4i1p1, r5ilp1 and r6ilp1 (for details see Taylor et al. 2010). Every run had different initial conditions, the same initialization method and perturbed physics. The data have been downloaded from the Earth System Grid Federation (ESGF). We analyse annual extremes of daily maximum and minimum surface air temperature $\left(T_{\max }\right.$ and $\left.T_{\min }\right)$ and of daily precipitation $(R R)$ as simulated by CMIP5 models in the historical experiment (years 1981-2010) and future experiments (years 2006-2035) averaged for six runs of every model. External forcing is based on RCP4.5 for the future. Representative concentrations pathways (RCPs) are defined by their total radiative forcing pathway and level by 2100 (Moss et al. 2010). The forcing is cumulative measure of anthropogenic emissions of greenhouse gases (GHGs) from all sources. RCP4.5 assumes sta- bilization without overshoot pathway to $4.5 \mathrm{~W} / \mathrm{m}^{2}$ at stabilization after 2100 .

Analyses focus on various climate extremes indices as introduced by the Joint CCl/CLIVAR/JCOMM Expert Team on Climate Change Detection and Indices - ETCCDI (Klein Tank et al. 2009):

1. Frost days: count of days where $T_{\min }$ $<0^{\circ} \mathrm{C}$.

2. Icing days: count of days where $T_{\max }$ $<0^{\circ} \mathrm{C}$.

3. Summer days: count of days where $T_{\max }>25^{\circ} \mathrm{C}$.

4. Wet days: count of days where $R R \geq 0 \mathrm{~mm}$.

5. Heavy precipitation days: count of days where $R R \geq 10 \mathrm{~mm}$.

6 . Very heavy precipitation days: count of days where $R R \geq 20 \mathrm{~mm}$.

Additionally, the indexes connected with thermal sensitivity of different species (Szwejkowski 1999) have been calculated:

7. Count of days where $T_{\min }<-25^{\circ} \mathrm{C}$.

8. Count of days where $T_{\min }<-20^{\circ} \mathrm{C}$.

9. Count of days where $T_{\min }<-15^{\circ} \mathrm{C}$.

10. Count of days where $\mathrm{T}_{\max }>10^{\circ} \mathrm{C}$.

11. Count of days where $\mathrm{T}_{\max }>15^{\circ} \mathrm{C}$.

12. Count of days where $\mathrm{T}_{\max }>20^{\circ} \mathrm{C}$.

For every above index mean annual (or seasonal) changes in future period relative to historical one were calculated and presented.

TABLE. The list of models used in the study

\begin{tabular}{|l|c|c|c|}
\hline Model & $\begin{array}{c}\text { Horizontal resolution } \\
\text { (longitude } \times \text { latitude) }\end{array}$ & Origin & Reference \\
\hline CanCM4 & $2.8125^{\circ} \times 2.7906^{\circ}$ & Canada & Merryfield et al. (2011) \\
\hline IPSL-CM5A-LR & $1.875^{\circ} \times 3.75^{\circ}$ & France & Dufresne et al. (2013) \\
\hline CNRM-CM5 & $1.4^{\circ} \times 1.4^{\circ}$ & France & Voldoire et al. (2012) \\
\hline MIROC5 & $1.4063^{\circ} \times 1.4008^{\circ}$ & Japan & Watanabe et al. (2010) \\
\hline MRI-CGCM3 & $1.1250^{\circ} \times 1.1215^{\circ}$ & Japan & Yukimoto et al. (2012) \\
\hline MIROC4h & $0.5625^{\circ} \times 0.5625^{\circ}$ & Japan & Sakamoto et al. (2013) \\
\hline
\end{tabular}




\section{RESULTS AND DISCUSSION}

The results of all analysed models show decrease in the number of frost days (Fig. 1), the smallest in CanCM4 (5-10 days per year), the largest in CNRM, about 20 days per year. No significant difference between the results of the models with the lowest and the highest spatial resolution is found.

Similar results were obtained for ice days (Fig. 2). The results of all models
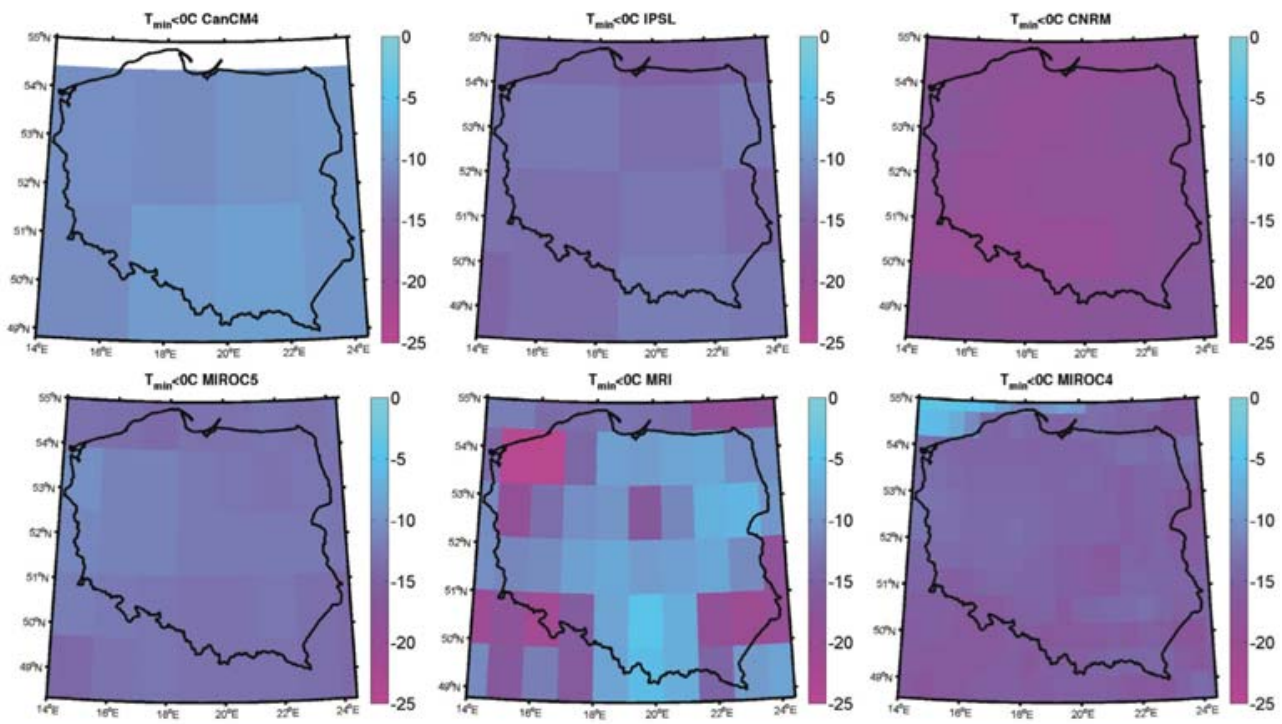

FIGURE 1. The average annual change in the number of days where $T_{\min }<0^{\circ} \mathrm{C}$
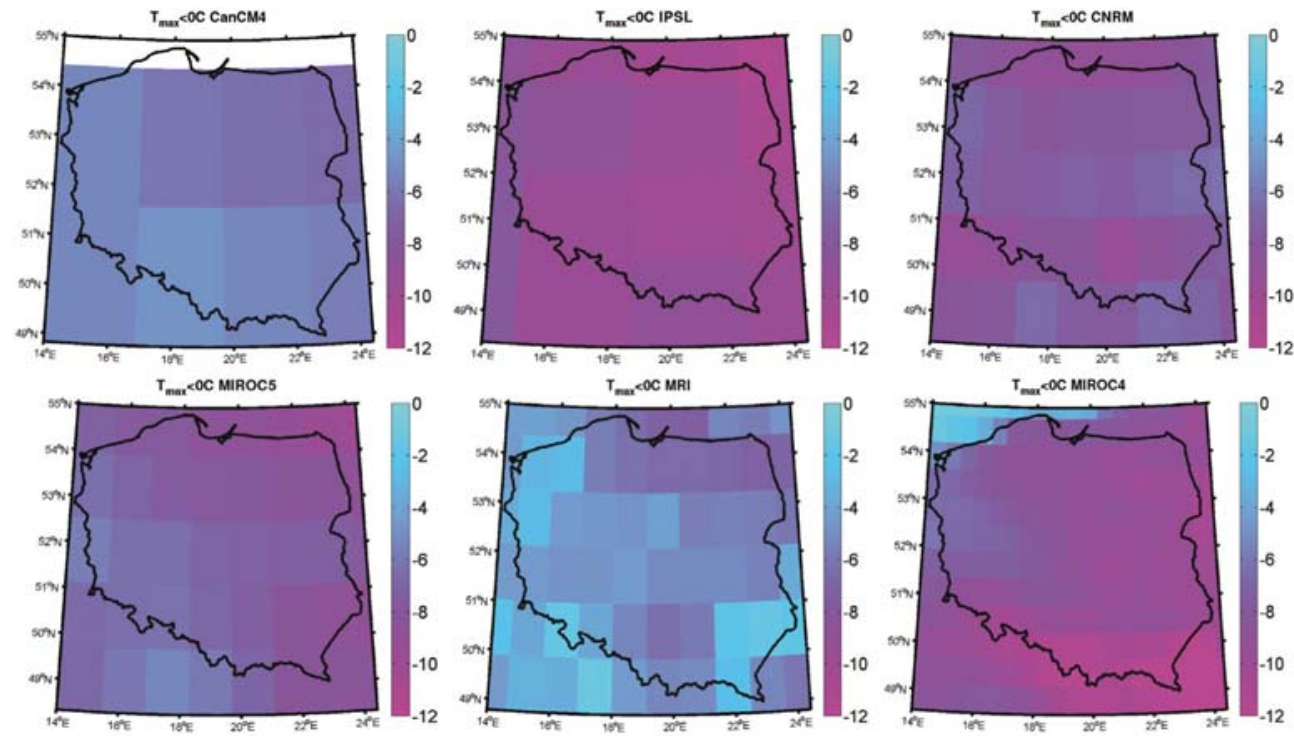

FIGURE 2. The average annual change in the number of days where $T_{\max }<0^{\circ} \mathrm{C}$ 
show decrease in the number of ice of the model. Even the model with the days, from 2-3 days per year (CanCM4, highest spatial resolution does not show MRI) to up to 12 days per year (IPSL, major differences within the country.

MIROC4). The diversity of results does The change in summer days is a litnot depend on the spatial resolution tle different (Fig. 3). For most models, an
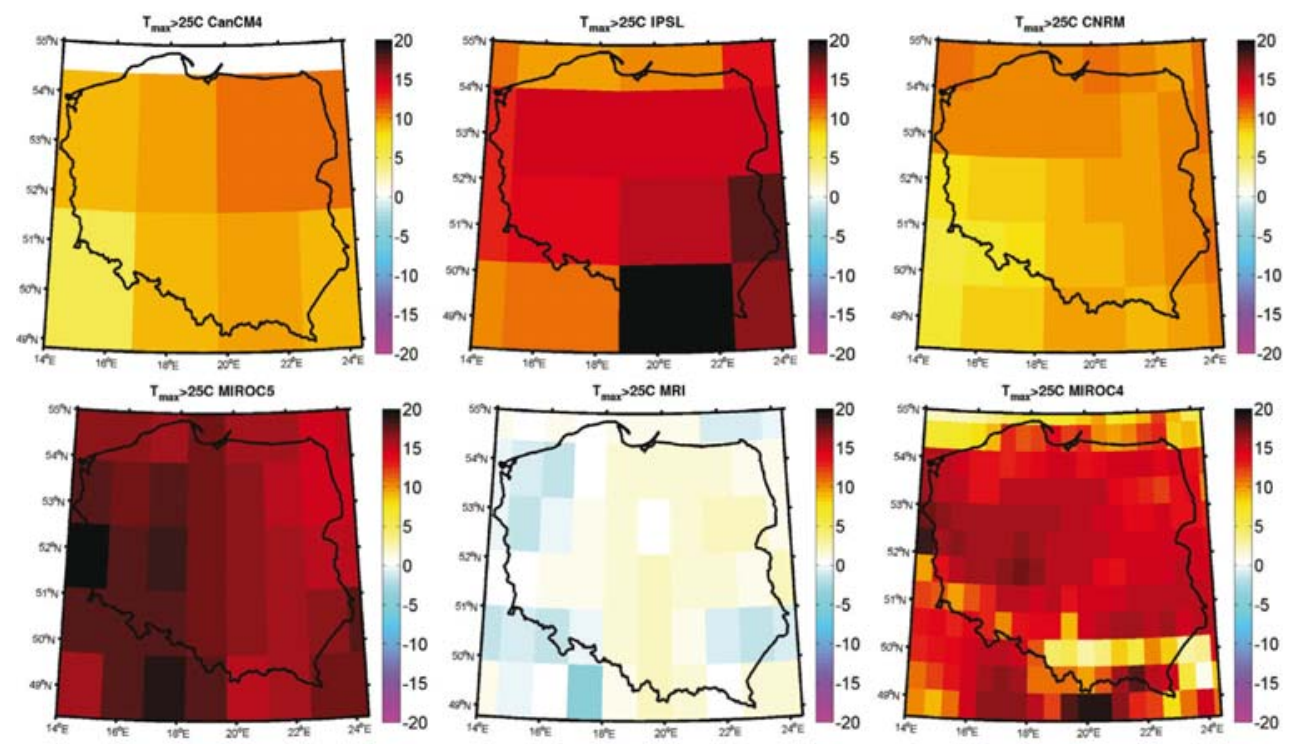

FIGURE 3. The average annual change in the number of days where $T_{\max }>25^{\circ} \mathrm{C}$
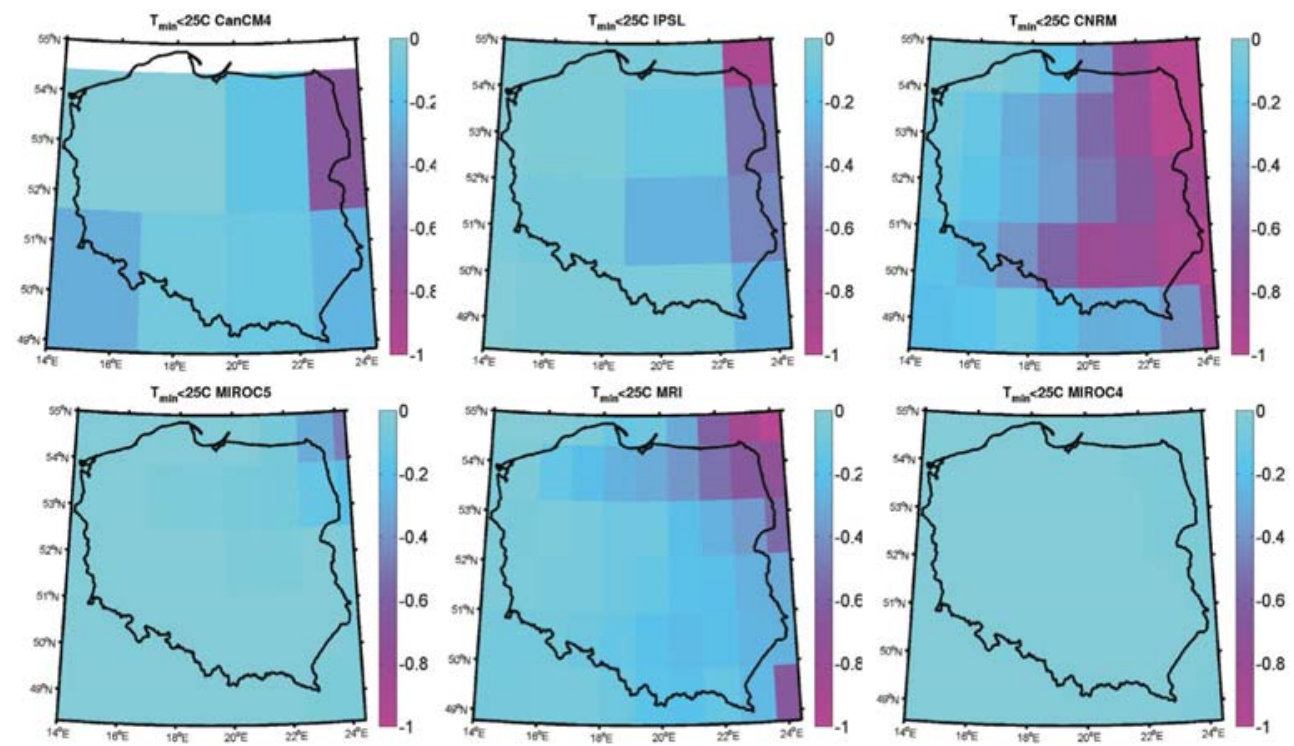

FIGURE 4. The average annual change in the number of days where $T_{\min }<-25^{\circ} \mathrm{C}$ 
increase in the number of summer days is observed, from 10 to even 20 days per year. Only one model (MRI) shows decrease in the number of summer days up to 5 days per year, but only for the western part of Poland. For the rest of the country increase in the number of summer days is observed, at about 5 days per year.

Different plants respond differently to harmful phenomena. The degree of risk is different for each species. Winter-seeded plants are exposed to more risks than plants seeded in spring. Plants seeded in autumn and sometimes even in late summer are exposed to factors affecting the ability to hibernate, such as too high temperature in the initial stages of the vegetation, or too low temperature, when they are in the anabiosis stage. Spring plants may have hampered vegetation due to both spring drought and late spring frosts.

One of the major phenomena harmful to plants is the low temperature. The most resistant to low winter temperature is the rye. No adverse reaction even when the temperature drops to about $-25^{\circ} \mathrm{C}$ (without snow cover, which in most cases acts as a thermal insulator) is found. In Figure 4 the change in the number of days with minimum temperature below $-25^{\circ} \mathrm{C}$ is presented. Each of the analysed models shows a small decrease in the number of such days (one day per year in the analysed period). No major differences between the results of individual models are found.

Wheat is more thermally sensitive than rye and takes temperatures below $-20^{\circ} \mathrm{C}$ badly (mainly due to the height of the main stem, closer to the soil surface than for rye). The all models predict a decrease in the number of such days, up to 3 days per year (Fig. 5).

The most thermally sensitive are canola and barley. Problems with wintering for these species are observed from $-15^{\circ} \mathrm{C}$ and below. Models show decrease
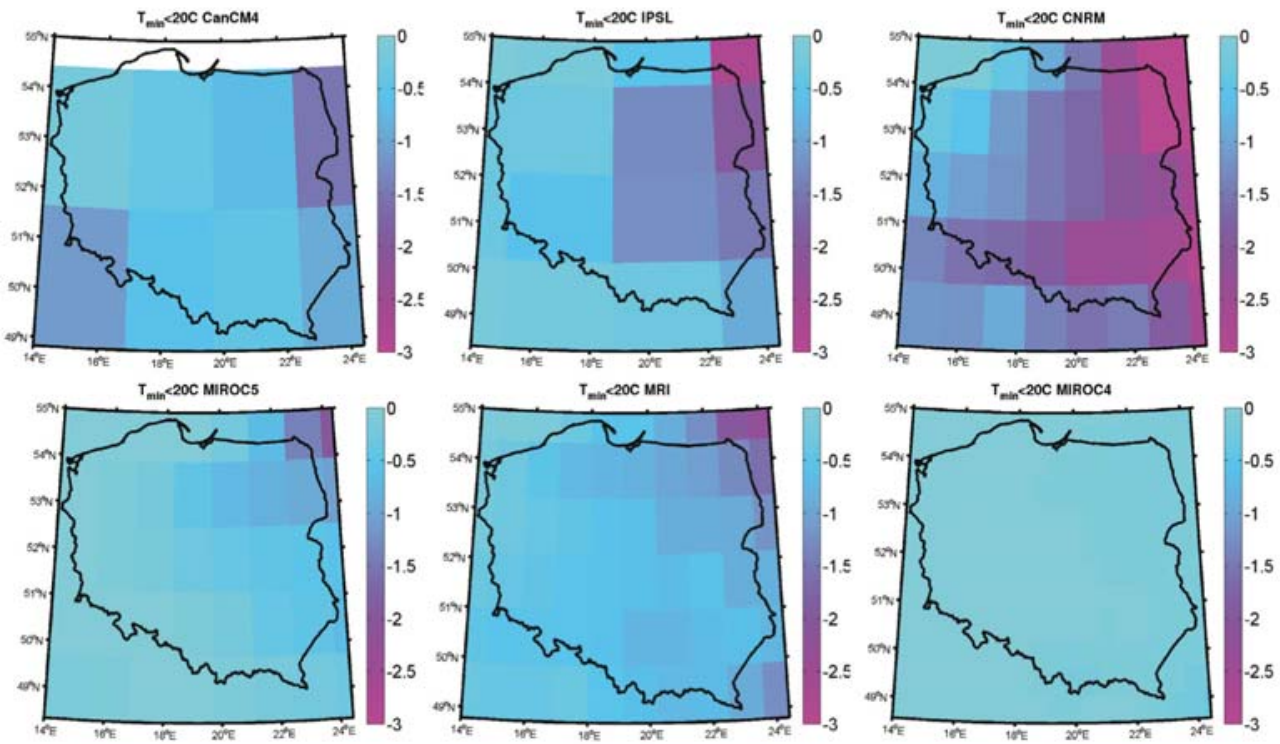

FIGURE 5. The average annual change in the number of days where $T_{\min }<-20^{\circ} \mathrm{C}$ 
in the number of such days, from 1 to 6 days per year (Fig. 6).

In general, the changes projected by individual models are similar. The largest change in the number of days with minimum temperature below the specified threshold is predicted by CNRM model, specifically in the eastern part of the country. This model also shows the largest variation in the Polish territory. The smallest decreases are observed in MIROC4, without significant spatial variations. It is worth noting that the model MIROC4 is a model with the highest spatial resolution.

The survival of wintering depends not only on thermal conditions in winter. Another important factor is the state of the plants before they enter anabiosis stage. The risk increases with both, the growth delay and excessive growth. The most sensitive to this factor is rape seeded at the beginning of August. Long and warm autumn may cause that plants will form more than four leaf pairs, what significantly lowers their ability to survive the winter.

Figure 7 shows the change in the number of days with maximum temperature above $10^{\circ} \mathrm{C}$ in the autumn. Most of the models predict an increase in the number of such days, from 5 to 7 days per year on average. Only MRI model predicts a decrease in the number of such days, about 2 days per year. On the following figures (Figs 8 and 9) the changes in the number of days with maximum temperature thresholds above 15 and $20^{\circ} \mathrm{C}$ are presented for the autumn as well. In both cases, only MRI predicts a decrease in the number of such days, while the other models predict an increase. This increase, however, is the smallest for CanCM4 and IPSL (3-4 days per year for both thresholds), the largest for MIROC5 (about 6 days per year for both thresholds).
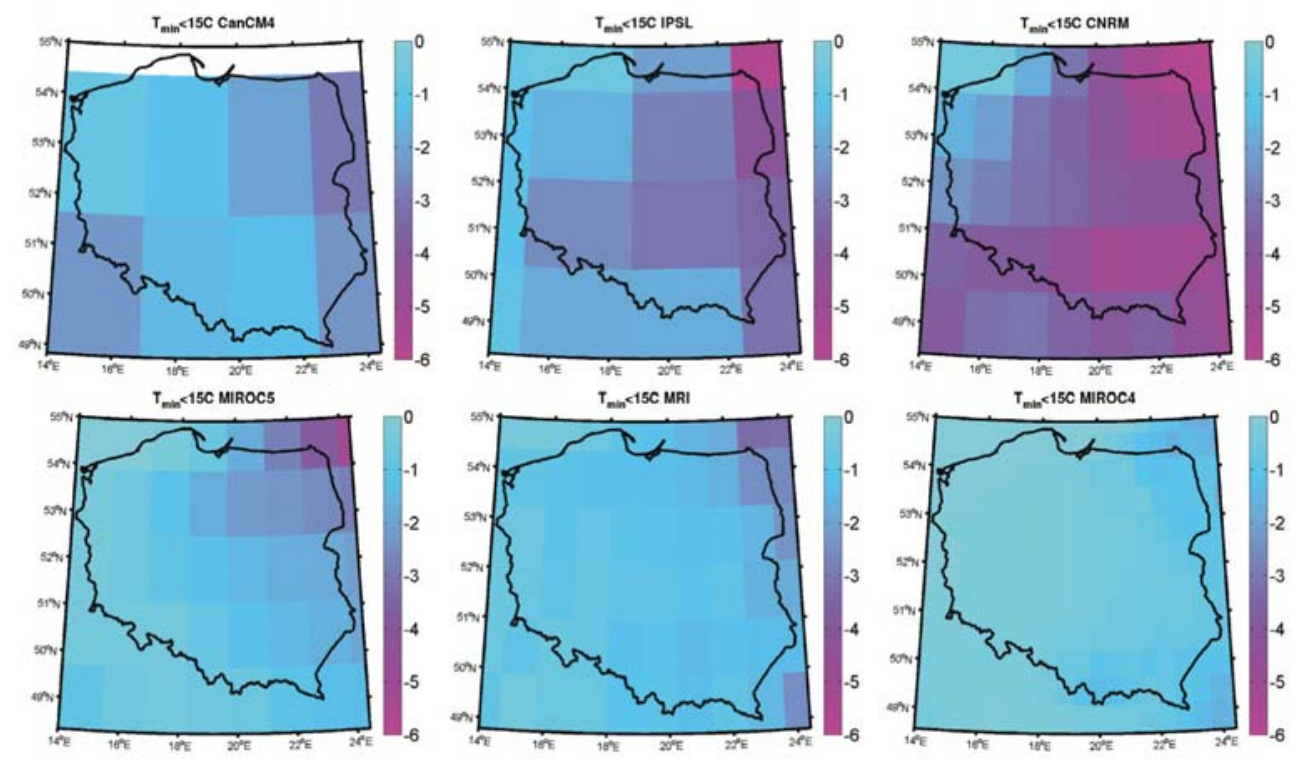

FIGURE 6. The average annual change in the number of days where $T_{\min }<-15^{\circ} \mathrm{C}$ 

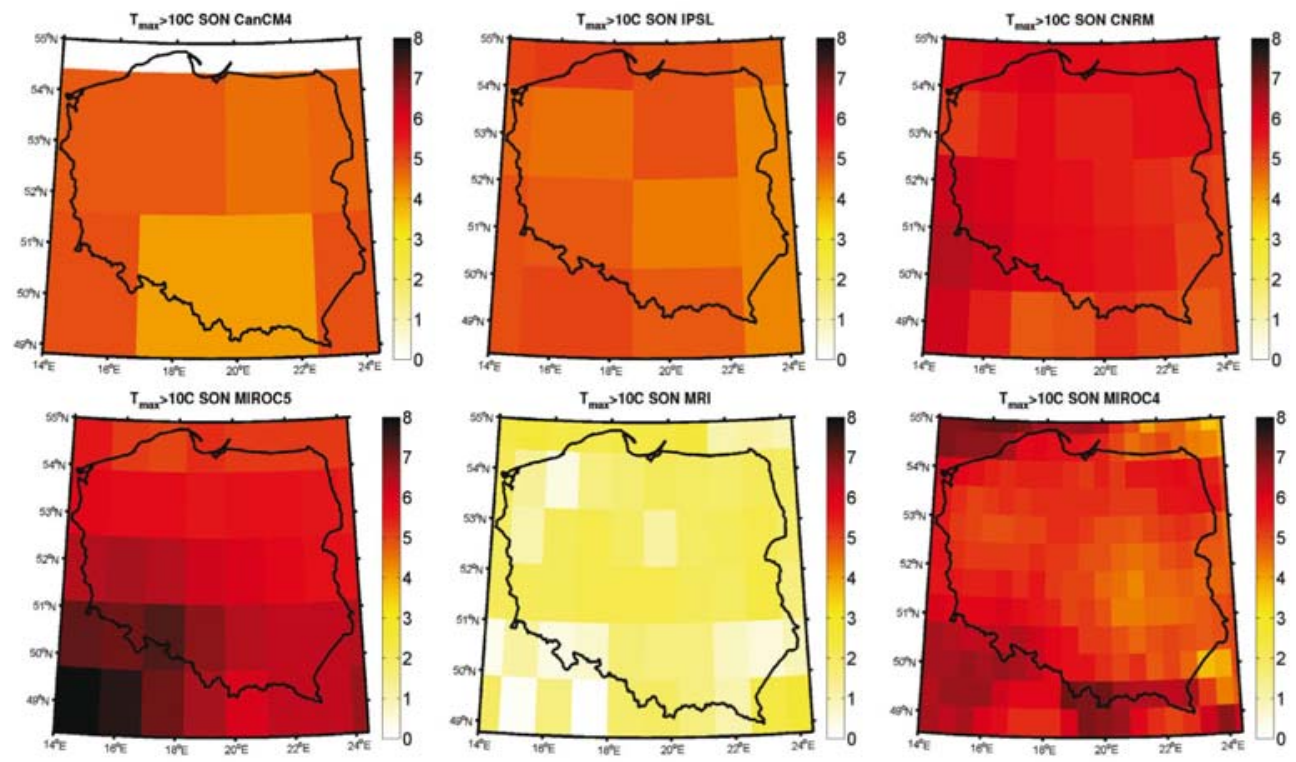

FIGURE 7. The average annual change in the number of days where $T_{\max }>10^{\circ} \mathrm{C}$ for autumn
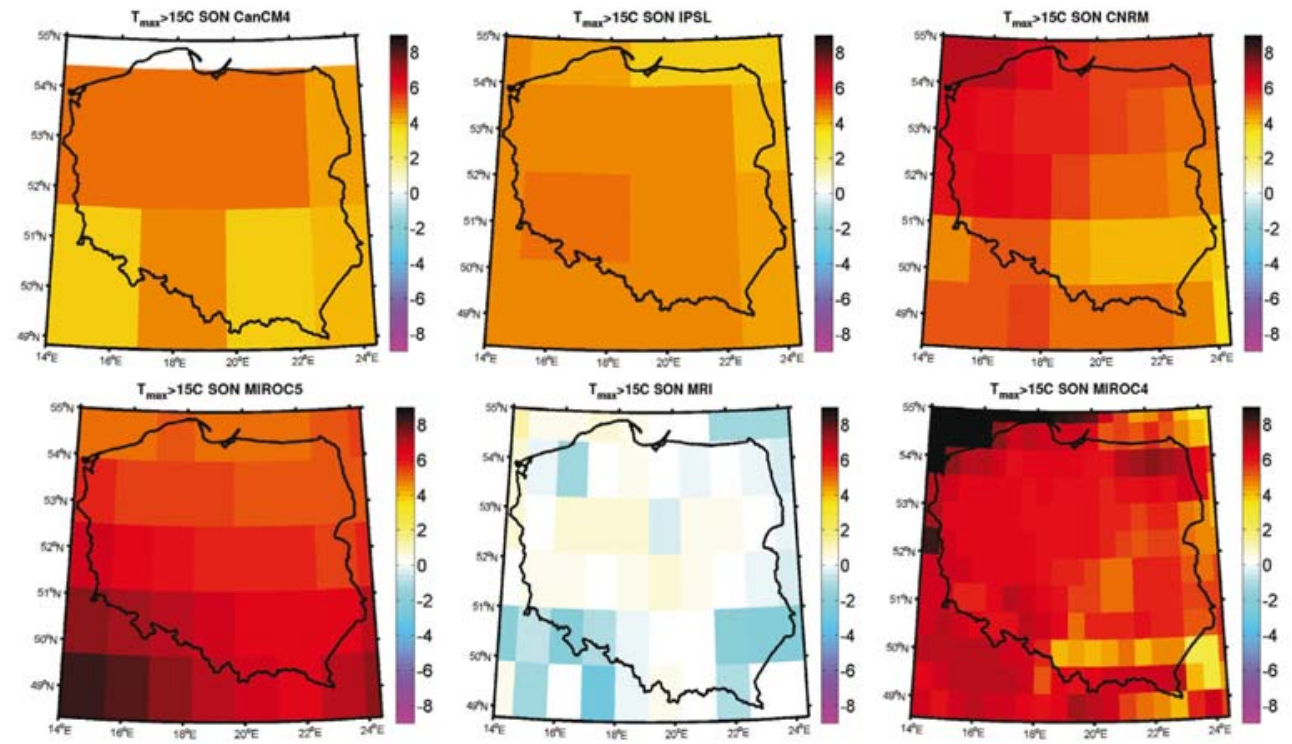

FIGURE 8. The average annual change in the number of days where $T_{\max }>15^{\circ} \mathrm{C}$ for autumn

Winter species are characterized by number of days with minimum temperaa gradual loss of thermal proof. Most dan- ture below $0^{\circ} \mathrm{C}$ in the spring (Fig. 10), the gerous are temperature drops in the spring. lowest in CanCM4 (1 day per year), the The models predict a decrease in the largest for CNRM (8-9 days per year). 

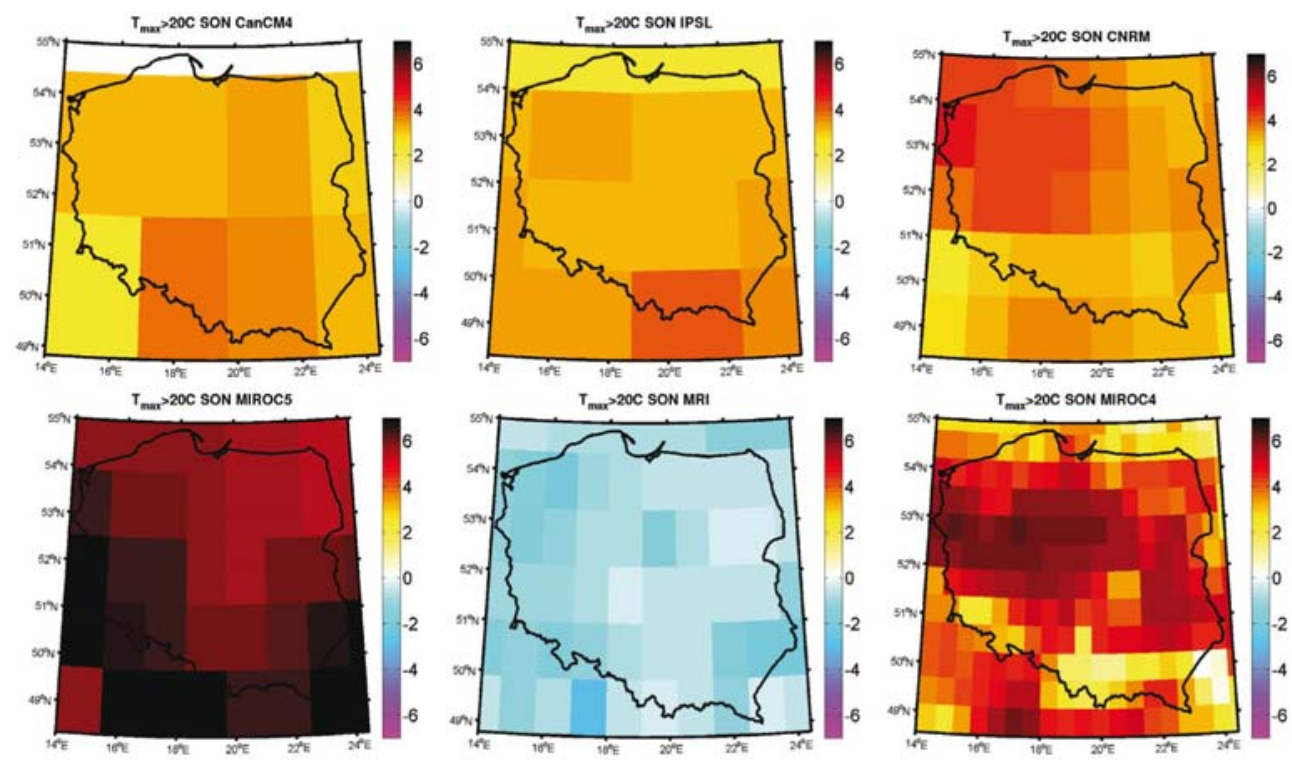

FIGURE 9. The average annual change in the number of days where $T_{\max }>20^{\circ} \mathrm{C}$ for autumn
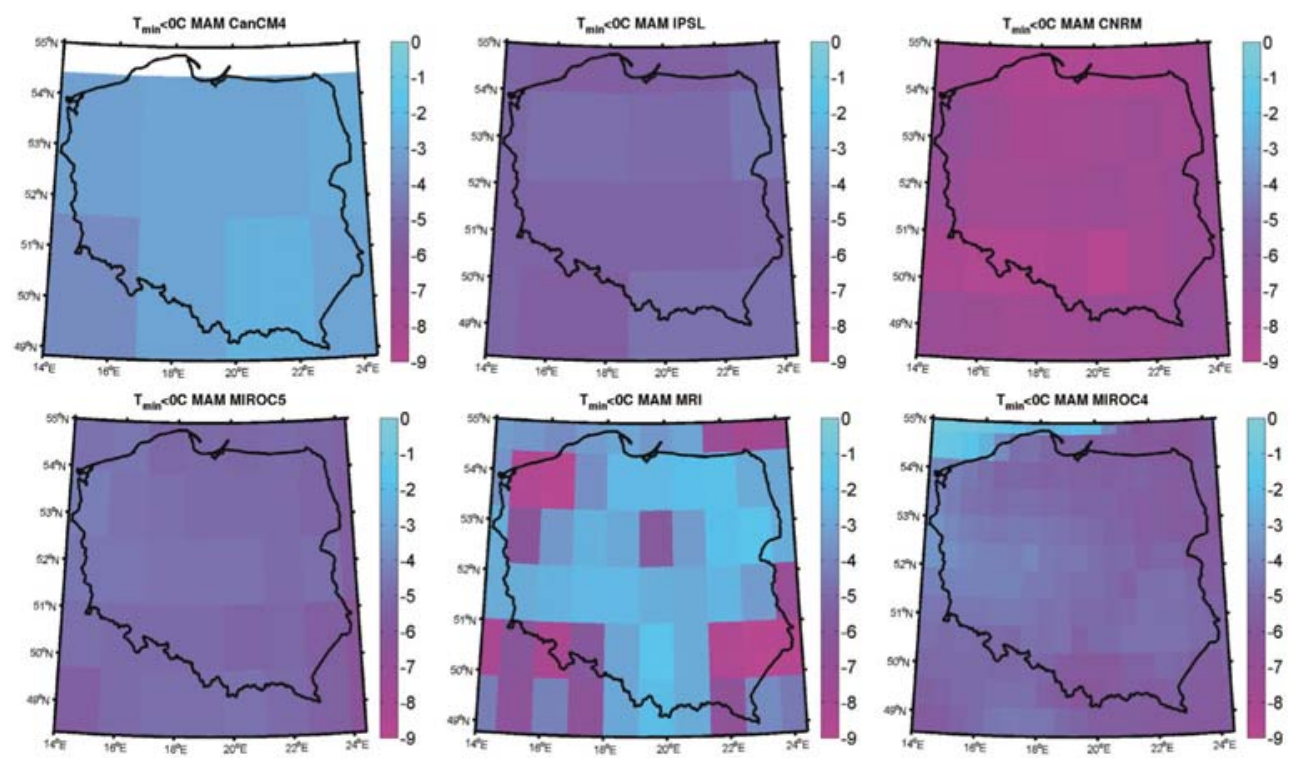

FIGURE 10. The average annual change in the number of days where $T_{\min }<0^{\circ} \mathrm{C}$ for spring

Excluding MRI model, the range of changes between different models is reasonable. This result is supported by Corti et al. (2012) who have showed good reliability of near-surface air temperature decadal prediction over Europe. Observed exceptional MRI's behaviour is supported by Miao et al. (2014) who 
have found this model simulating the lowest surface air temperature trend in $21^{\text {st }}$ century. This may be caused by one of the lowest among all the CMIP5 models sensitivity of this model (Andrew 2012).

Another important factor for plant growth is precipitation. However, even if the plant needs are met in the annual amount of rainfall, dangerous are situations of prolonged drought or excessive rainfall. The former can be mitigated by building an appropriate irrigation infrastructure. Extreme precipitation, however, causes difficulties in terms of field work. Even modest but prolonged rainfall makes it impossible to perform a number of agricultural operations.

Attention has to be drawn to the phenomenon of water erosion, which causes significant losses in agricultural production. About $20 \%$ of the country is under the risk of this phenomenon. The first signs of surface erosion are observed when daily rainfall exceeds $10 \mathrm{~mm}$, while the strong erosion caused by rainfall daily occurs above $20 \mathrm{~mm}$.

The rainfall is more difficult parameter for prediction because it is parameterized in the numerical models and the rainfall field is discontinuous. Figure 11 shows the average annual change in the number of wet days. The model results differ significantly. IPSL predicts a decrease in the number of such days, 5 days per year throughout the country, MRI and MIROC4 from 0 to 5 days. CanCM4 predicts a decrease of 2-3 days per year in the northern part of Poland, while in the southern part an increase is 4 days per year. CNRM and MIROC5 show the increase in the counts of wet days from 4 to 8 days in a year.

The changes in the counts of heavy (Fig. 12) and very heavy (Fig. 13) precipitation days are different between models. Some of them predict an increase, the others show an increase.
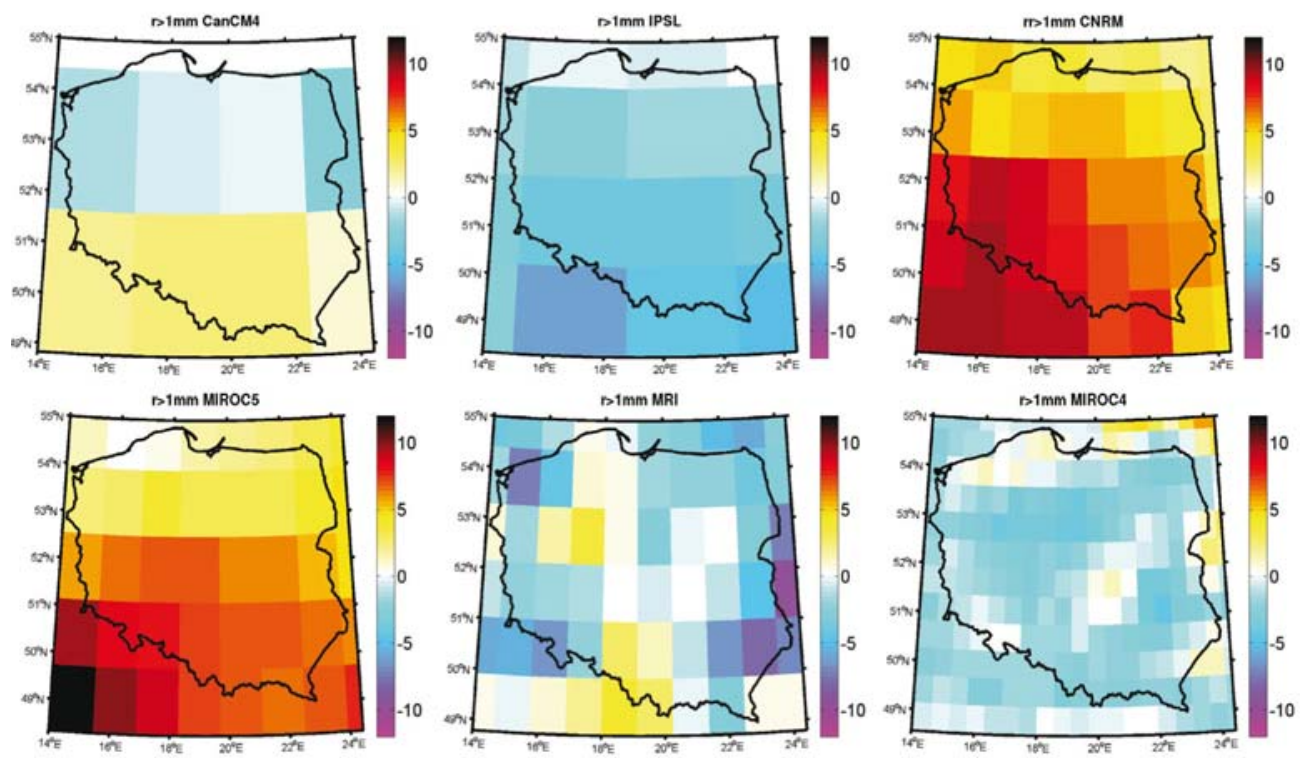

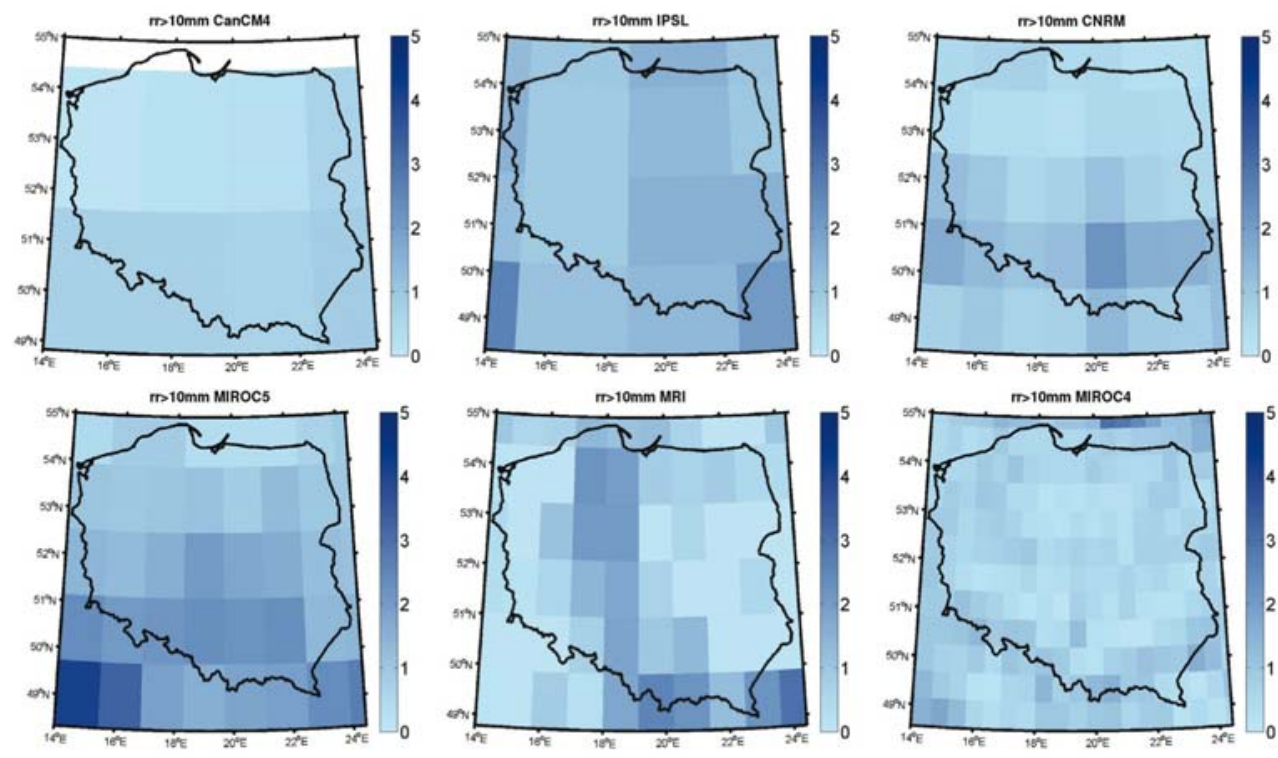

FIGURE 12. The average annual change in the number of days with precipitation $\geq 10 \mathrm{~mm}$
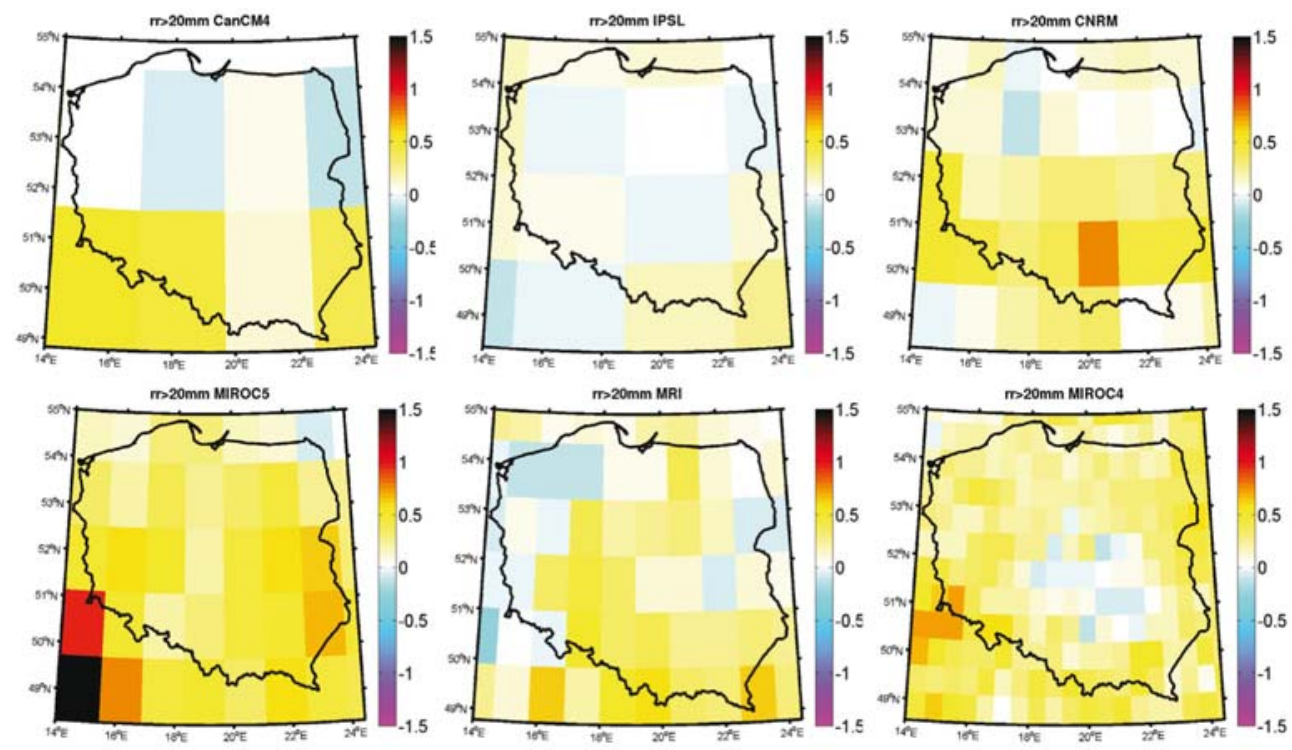

FIGURE 13. The average annual change in the number of days with precipitation $\geq 20 \mathrm{~mm}$

\section{CONCLUSIONS}

Most recent results of global climate simulations for Poland showed changes of climate indices as a result of observed global temperature increase. Increase of greenhouse gases (GHG) concentrations results in decrease of frost and icing days and days with more extreme low temperatures and in increase of summer 
days and days with more extreme high temperatures. An increase in the number of days with very heavy precipitation is also projected. Future crop production may be affected by prolonged drought, lack of snow cover in the winter's low temperature periods or spring frost. However, impacts on the production are more complicated and depend on interaction between thermal and water conditions.

Rising demands on food are adding to pressure on the agriculture which is one of major contributor to GHG emissions as well. Since the 1990s agriculture sector considerably contributed to reduction of GHG emissions increasing production volume at the same period. This was achieved by switching to cost-effective practices. On the other hand, in Poland, share of agriculture in national total GHG emissions is nearly the same as in European Union but the agriculture's emissions share per domestic gross product is nearly twice larger (OECD 2014). Robust introduction of cost-effective options could be one of mitigation way in the country.

Climate adaptation techniques in agriculture can exploit sustainable resource management allowing concurrently to achieve higher productivity, improve resource-use efficiency and reduce GHG emission intensity. Presented results pose challenges for crop production adaptation. One of the ways can be a substitution of one crop with another (Mariani 2008) or using more efficient irrigation methods. However, besides thermal conditions and water resources, many other important factors play a role and all of them should be integrally considered like for example solar radiation, nutrient availability or disorders due to weeds and cryptogams.

\section{REFERENCES}

ANDREWS T., GREGORY J.M., WEBB M.J., TAYLOR K.E. 2012: Forcing, feedbacks and climate sensitivity in CMIP5 coupled atmosphere-ocean climate models. Geophys. Res. Lett. 39, L09712. doi: 10.1029/2012GL051607.

CORTI S., WEISHEIMER A., PALMER T.N., DOBLAS-REYES F.J., MAGNUSSON L. 2012: Reliability of decadalpredictions. Geophys. Res. Lett.39, L21712. doi: 10.1029/2012GL053354.

DUFRESNE J.-L. et al. 2013: Climate change projections using the IPSL-CM5 Earth System Model: from CMIP3 to CMIP5. Clim. Dyn. 40, 2123-2165. doi: 10.1007/s00382-012-1636-1.

GODDARD L. et al. 2013: A verification framework for interannual-to-decadal predictions experiments. Clim. Dyn. 40, 245-272. doi: 10.1007/s00382-0121481-2.

IPCC 2014: Climate Change: Impacts, Adaptation, and Vulnerability.

KLEIN TANK A.M.G., ZWIERS F.W., ZHANG X. 2009: Guidelines on Analysis of extremes in a changing climate in support of informed decisions for adaptation. WCDMP-72, WMO-TD 1500.

KUNDZEWICZ Z., KOZYRA J. 2011: Ograniczenie wpływu zagrożeń klimatycznych $\mathrm{w}$ odniesieniu do rolnictwa i obszarów wiejskich [Reducing impacts of climatic threats to agriculture and rural areas]. Polish Journal of Agronomy 7, 68-81 (Engl. summ.).

MARIANI L. 2008: Italian agriculture and climatic risk. Ital. J. Agrometeorol. 2, $10-17$.

MEEHLG.A. et al. 2009: Decadal Prediction: Can It Be Skillful? Bulletin of the American Meteorological Society 90, 1467-1485. doi: 10.1175/2009BAMS2778.1.

MERRYFIELD W.J., DENIS B., FONTECILLA J., LEE W., KHARIN V., HODGSON J., ARCHAMBAULT B. 2011: The Canadian seasonal to interannual prediction system (CanSIPS). CMC technical report. 
MIAO C., DUAN Q., SUN Q., HUANG Y., KONG D., YANG T., YE A., DI Z., GONG W. 2014: Assessment of CMIP5 climate models and projected temperature changes over Northern Eurasia. Environ. Res. Lett. 9, 055007. doi: 10.1088/17489326/9/5/055007.

MOSS R.H. et al. 2010: The next generation of scenarios for climate change research and assessment. Nature 463, 747-756. doi: 10.1038 /nature 08823 .

OECD 2014: Green Growth Indicators for Agriculture. Paris.

SAKAMOTO T.T. et al. 2012: MIROC4h A New High-Resolution AtmosphereOcean Coupled General Circulation Model. Journal of the Meteorological Society of Japan. II. 90, 325-359. doi: 10.2151/ jmsj.2012-301.

SZWEJKOWSKI Z. 1999: Basis of agrometeorology. Wydawnictwo WSA, Łomża (in Polish).

TAYLOR K.E., BALAJI V., HANKIN S., JUCKES M., LAWRENCE B. 2010: CMIP5 and AR5 Data Reference Syntax (DRS). URL http://cmip-pcmdi.llnl.gov/ cmip5/docs/cmip5_data_reference_syntax_v0-25 clean.pdf.

TAYLŌR K.E.E., STOUFFER R.J., MEEHL G.A. 2012: An Overview of CMIP5 and the Experiment Design. Bulletin of the American Meteorological Society 93, 485-498. doi: 10.1175/BAMS-D-1100094.1.

VOLDOIRE A. et al. 2013: The CNRM-CM5.1 global climate model: description and basic evaluation. Clim. Dyn. 40, 2091-2121. doi: 10.1007/s00382-0111259-y.
WATANABE M. et al. 2010: Improved Climate Simulation by MIROC5: Mean States, Variability, and Climate Sensitivity. J. Climate 23, 6312-6335. doi: 10.1175/2010JCLI3679.1.

YUKIMOTO S. 2012: A New Global Climate Model of the Meteorological Research Institute: MRI-CGCM3 - Model Description and Basic Performance. Journal of the Meteorological Society of Japan. II. 90A, 23-64. doi: 10.2151/jmsj.2012-A02.

Streszczenie: Potencjalny wplyw przyszlych zmian klimaycznych na produktywność upraw wybranych roślin w Polsce. W pracy przedstawiono przyszłe projekcje zmian wybranych wskaźników klimatycznych, na podstawie których oceniono możliwy wpływ zmian klimatu na produktywność wybranych roślin. Wykorzystano wyniki symulacji globalnych modeli klimatycznych CMIP5 dla przyszłego (2006-2035) oraz historycznego okresu (1981-2010). Modele przewidują spadek liczby dni z ekstremalnie niską temperaturą oraz wzrost liczby dni z ekstremalnie wysoką temperaturą. Przewidywany jest również wzrost dni z bardzo dużymi wielkościami opadu. Nie wszystkie skutki zmian klimatu niosą za sobą negatywny wpływ na produktywność upraw w Polsce, ale wszystkie wymuszają potrzebę praktycznego wprowadzenia do polskiego rolnictwa strategii dostosowawczych i adaptacyjnych.

\section{MS received May 2014}

\section{Authors' address:}

Barbara Brzóska, Adam Jaczewski

Instytut Meteorologii i Gospodarki Wodnej

Państwowy Instytut Badawczy

ul. Podleśna 61, 01-673 Warszawa, Poland

e-mail: Barbara.Brzoska@imgw.pl, Adam.Jaczewski@imgw.pl 